\title{
The ErbB2 and ErbB3 receptors and their ligand, neuregulin-1, are essential for development of the sympathetic nervous system
}

\author{
Stefan Britsch, ${ }^{1}$ Li Li, $^{1}$ Susanne Kirchhoff, ${ }^{3}$ Franz Theuring ${ }^{4}$ Volker Brinkmann, ${ }^{2}$ \\ Carmen Birchmeier, ${ }^{1,5}$ and Dieter Riethmacher ${ }^{1}$ \\ Departments of ${ }^{1}$ Medical Genetics and ${ }^{2}$ Cell Biology, Max-Delbrück-Center (MDC) for Molecular Medicine, 13122 Berlin, \\ Germany; ${ }^{3}$ Institut für Genetik, Universität Bonn, 53117 Bonn, Germany; ${ }^{4}$ Institut für Pharmakologie and Toxikologie, \\ Universitätsklinik Charité Berlin, 10117 Berlin, Germany
}

\begin{abstract}
Neuregulins (NDF, heregulin, GGF ARIA, or SMDF) are EGF-like growth and differentiation factors that signal through tyrosine kinase receptors of the ErbB family. Here, we report a novel phenotype in mice with targeted mutations in the erbB2, erbB3, or neuregulin-1 genes. These three mutations cause a severe hypoplasia of the primary sympathetic ganglion chain. We provide evidence that migration of neural crest cells to the mesenchyme lateral of the dorsal aorta, in which they differentiate into sympathetic neurons, depends on neuregulin-1 and its receptors. Neuregulin-1 is expressed at the origin of neural crest cells. Moreover, a tight link between neuregulin-1 expression, the migratory path, and the target site of sympathogenic neural crest cells is observed. Sympathetic ganglia synthesize catecholamines in the embryo and the adult. Accordingly, catecholamine levels in mutant embryos are severely decreased, and we suggest that the lack of catecholamines contributes to the embryonal lethality of the erbB3 mutant mice. Thus, neuregulin-1, erbB2, and erbB3 are required for the formation of the sympathetic nevvous system; the block in development observed in mutant mice is caused by a lack of neural crest precursor cells in the anlage of the primary sympathetic ganglion chain. Together with previous observations, these findings establish the neuregulin signaling system as a key regulator in the development of neural crest cells.
\end{abstract}

[Key Words: Development; neural crest cells; migration; adrenal medulla; catecholamines; tyrosine kinase receptor]

Received January 23, 1998; revised version accepted A pril 20, 1998.

N eural crest cells constitute a transient and migratory cell population that generates the majority of the peripheral nervous system and facial skeleton as well as other derivatives such as melanocytes. After an epithelialmesenchymal transition, neural crest cells detach from the epithelium of the dorsal neural tube and start their migration (Le Douarin 1982). The embryonal ectoderm plays a key role in formation of neural crest cells; members of the TGF- $\beta$ family have been demonstrated recently to induce dorsalization of the neural tube and the generation of neural crest cells (Liem et al . 1997). Cellular interactions that occur during migration and at the target sites of migration control survival, growth, motility, and differentiation of neural crest cells (Le Douarin et al. 1994; Anderson 1997). The identification of molecules that govern neural crest cell development is an area of active research.

${ }^{5}$ Corresponding author.

E-MAIL cbirch@mdc-berlin.de; FAX 49-30-9406 3765.
The sympathetic nervous system derives from neural crest cells that migrate to the mesenchyme lateral of the dorsal aorta. Local signals provided by cells at the target site allow survival and also specify sympathogenic differentiation. A subpopulation of sympathogenic neural crest cel Is depends on a signal given by the c-Ret tyrosine kinase receptor for survival at the target (Schuchardt et al. 1994; Durbec et al. 1996). Members of the TGF- $\beta$ family (BM P-2, BM P-4, and BM P-7 ) give the inductive signals that direct the differentiation of sympathetic neurons (Reissmann et al. 1996; Shah et al. 1996). Differentiation of sympathetic neuronal precursors is characterized by the expression of Mash-I and Phox2a, two transcription factors that first appear after the neural crest cells condense laterally of the dorsal aorta. Subsequently, enzymes involved in biosynthesis of catecholamines are produced, for example, tyrosine hydroxylase (TH) and dopamine $\beta$-hydroxylase (DBH) (Cochard et al. 1978; Guillemot and Joyner 1993; Ernsberger et al. 1995; Groves et al. 1995; Tiveron et al. 1996). Neuronal pre- 
cursors in the anlage of the primary sympathetic ganglion chain again give rise to migrating cells at subsequent developmental stages. These cells move to the adrenal gland and into the mesentery to form chromaffin cells of the adrenal medulla and the ganglia of the visceral plexus, respectively (Le Douarin 1986).

Tyrosine kinase receptors (c-Ret, ErbB3/ErbB2, and c$\mathrm{Kit}$ ) and their ligands have been impl icated in the control of the devel opment of neural crest cells (LeDouarin et al . 1994; Wehrle-Haller and Weston 1997). The neuregulin-1 gene encodes different isoforms of an EGF-like growth and differentiation factor that are also known as NDF, heregulin, GGF, ARIA, or SMDF (Holmes et al. 1992; Wen et al. 1992; Falls et al. 1993; Marchionni et al. 1993; Ho et al. 1995). N eural crest cells and various other cell types, like glial, muscle, or epithelial cells, respond to neuregulin-1 by growth and differentiation (for review, see Lemke 1996; Burden and Yarden 1997). N euregulin-induced cellular responses are mediated by tyrosine kinase receptors of the ErbB family. Biochemical and genetic data indicate that the functional neuregul in receptors are ErbB3/ErbB2 or ErbB4/ErbB2 heterodimers (Plowman et al. 1993; Carraway and Cantley 1994; Sliwkowski et al. 1994; Tzahar et al. 1994; Beerli et al. 1995; Horan et al. 1995; Riese et al . 1995; Wallasch et al. 1995). Distinct receptor combinations are essential in different developmental events: The ErbB2 and ErbB4 receptors cooperate in transmission of neuregul in-1 si gnals in the heart, whereas ErbB2 and ErbB3 cooperate in neural crest cells (Gassmann et al. 1995; Lee et al. 1995; Meyer and Birchmeier 1995; Erickson et al. 1997; Riethmacher et al. 1997). Two distinct neural crest cell derivatives, neurons of cranial ganglia and Schwann cell precursors, were reported previously to depend on neuregulin-1 (Meyer and Birchmeier 1995; Lee et al. 1995; Erickson et al. 1997; Riethmacher et al. 1997). The precise developmental event that requires the neuregulin-1 signal has not been elucidated.

Here, we characterize a novel function of the neuregulin signaling system in the development of the sympathetic nervous system. In neuregul in-1, erbB2, and erbB3 mutant mice, a severe hypoplasia of the primary sympathetic ganglion chain is observed. In the absence of an intact neuregulin signaling system, the distribution of neural crest cells during the migratory process is al tered, and neural crest cells appear to be unable to migrate to the anlage of the primary sympathetic ganglion chain. Sympatho-adrenergic cells are the major source of catecholamines in the embryo and the adult. We show that catecholamine levels are severely reduced in erbB3 mutant mice and suggest that this contributes to the embryonal lethality of mutant embryos. Thus, neuregulin-1 and the ErbB2/ErbB3 receptors are required to maintain the migratory ability of sympathogenic neural crest cells. Moreover, these molecules are also essential for the development of other cells types derived from the neural crest, that is, specific glial cells and cranial sensory neurons. N euregul in and the ErbB2/ErbB3 receptors thus emerge as a major driving force in the development of neural crest cells.

\section{Results}

Appearance of the primary sympathetic ganglion chain in E10.5 embryos mutant for the erbB2, erbB3, or neuregulin-1 genes

We have identified a novel phenotype in embryos with mutations in the neuregulin/ErbB signaling system, namely a defect in the development of the sympathetic nervous system. The evidence was obtained by the analysis of embryos with mutations in erbB2, erbB3, and neuregulin-1. The generation of mouse lines with ablated neuregulin-1 and erbB3 genes has been described elsewhere (M eyer and Birchmeier 1995; Riethmacher et al. 1997). The mutant erbB2 (erbB2 ${ }^{l a c z}$ ) allele used in this study was generated by the fusion of lacZ sequences to an exon encoding the cytopl asmic juxtamembrane domain of ErbB2 (Fig. 1a,b). The allele encodes an ErbB2$\beta$-galactosidase fusion protein that lacks the tyrosine kinase domain but contains intact extracellular and transmembrane domains. Antibodies against the carboxyl terminus of ErbB2 demonstrated the absence of wildtype protein in homozygous mutant embryos (Fig.1c). Homozygous mutant erbB2 ${ }^{\text {lacz }}$ embryos die at midgestation (E10.75); they display a lack of trabecules in the heart ventricle and an abnormal appearance of cranial ganglia (see also Lee et al. 1995). M oreover, numbers of early Schwann cell precursors that accompany projecti ons of sensory and motor neurons are reduced in erbB2 mutant embryos on E10.5 (not shown), a phenotype we described previously for neuregulin-1 and erbB3 mutant mice (Meyer and Birchmeier 1995; Riethmacher et al. 1997).

When we examined the sympathetic nervous system of the mouse strains with mutations in neuregulin-1, erbB2, and erbB3, we observed a severe reduction of neuronal precursors present in the primary sympathetic ganglion chain, which is located laterally of the dorsal aorta (see Fig. 2). These precursors were identified by in situ hybridization with a probe specific for Phox2a, which encodes a transcription factor expressed in sympathetic neurons and their precursors (Tiveron et al. 1996; Morin et al . 1997). In particular, we observed that Phox2a-positive cells in the caudal part (arrows) of the sympathetic ganglion chain are rare, whereas the rostral portion (arrowheads) is less affected (Fig. 2b,d,f). A similar reduction of precursors of sympathetic neurons was observed by in situ hybridization with a M ash-I-specific probe (see also Fig. 3g,h).

Neural crest cells require the neuregulin signaling system during migration to the mesenchyme lateral of the dorsal aorta

To determine the stage at which these deficits in development of the sympathetic nervous system become first apparent, we analyzed generation and migration of neural crest cells that form the sympathetic ganglion chain. Expression of ErbB3 in neural crest cells begins when they emerge from the neural tube (Fig. 3c, see also section in Fig. 4a) and continues during migration of the 
a
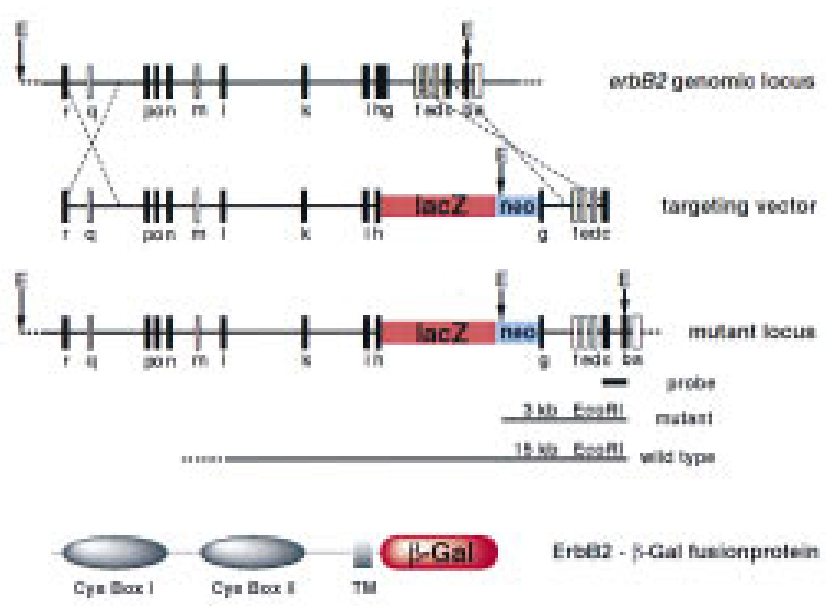

b
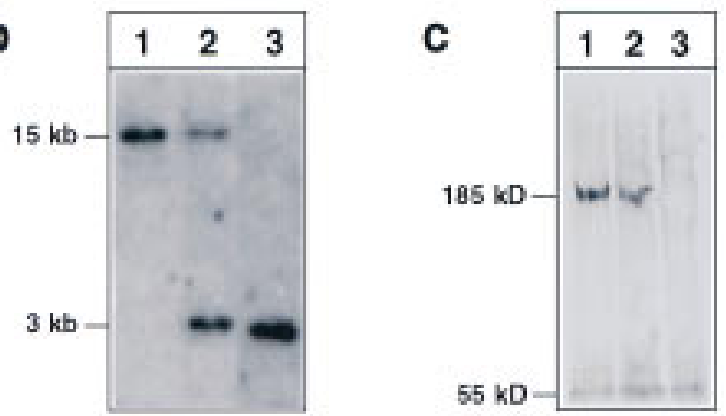

Figure 1. (a) Strategy applied to mutate the erbB2 gene. The genomic structure of the wild-type erbB2 allel e is schematically shown at the top. The schematic structures of the targeting vector and of the mutant erbB2 locus are displayed. Exon sequences are indicated by boxes; exons indicated in white were mapped, whereas the position of the exons indicated in black were determined by sequence. In the targeting vector, lac $Z$ was fused in frame to exon $\mathrm{h}$. The inserted neomycin resistance gene (neo) is driven by the PGK promoter. The probe used for Southern hybridization and sizes of predicted fragments obtained after EcoRI digestion of genomic DN A containing the wild-type and mutant alleles are indicated. The structure of the predicted fusion protein encoded by the mutated erbB2 locus is shown at the very bottom. (b) Southern blot analysis of genomic DNA from wild-type embryos (lane 1), and embryos heterozygous (lane 2), or homozygous (lane 3) for the mutant erbB2 al leles; for hybridization, a genomic DNA fragment indicated above was used as probe. (c) Western bl ot analysis of the ErbB2 receptor on protein extracts of embryonal hearts from wild-type embryos (lane 1), heterozygous (lane 2), and homozygous (lane 3) mutant embryos.

neural crest cells (Fig. 3a). No difference in the emergence of ErbB3-positive cells from the neural tube of control and erbB2 mutant embryos was apparent in the trunk (arrowheads in Fig. 3c,d). However, a severe reduction in the numbers of ErbB3-expressing cells that migrate beyond the anlage of the dorsal root gangl ia and in the area where neural crest cells start to differentiate into sympathetic neurons was observed in the mutant embryos (Fig. 3e and f; cf. gand h). $N$ eural crest cells that derive from the postotic hindbrain al so contribute to the rostral portion of the sympathetic nervous system (Durbec et al. 1996). The streams of postotic crest cells that migrate to the anlage of the enteric and sympathetic nervous system appeared unchanged in erbB2 mutant embryos (not shown). Deficits in neural crest cells that contribute to cranial ganglia were apparent (arrowheads in Fig. 3a,b).

Vibratome sections of control embryos hybridized with probes specific for ErbB3 or p75 ${ }^{\mathrm{NTR}}$ were used to visualize the migratory path of sympathogenic neural crest cells that extends from the dorsal neural tubeto the mesenchyme lateral of the dorsal aorta (Fig. $4 a, C)$. In erbB2 $2^{-1-}$ embryos, neural crest cells were scarce at positions ventral of the neural tube and lateral of the dorsal aorta (Fig. 4b,d). This scarcity at ventral positions contrasted with a more compact appearance of neural crest cells at dorsal positions (Fig. 4b,d). The reduced numbers at ventral positions and the accumulation at dorsal positions was cl early apparent in thin sections stained with p75 NTR -specific antibodies (Fig. 4g,h). A similar distribution of neural crest cells was observed in neuregulin-1 or erbB3 mutant embryos at this stage (not shown).

To quantify this change in distribution of neural crest cells, we determined the numbers of $p 75^{N T R}$-positive cells along the migratory path and at the target site of sympathogenic neural crest cells on consecutive sections that together covered the entire forelimb region (Fig. 5a). N umbers of neural crest cells in a dorsal position were increased in erbB2, erbB3, and neuregulin-1 mutant embryos (Fig. 5a, dark gray bars); these cells appeared frequently clustered and were di rectly contacting each other. The numbers of labeled cells ventral of the neural tube and lateral of the dorsal aorta were decreased (Fig. 5a, light gray and white bars, respectively). This change in distribution of neural crest cells was not accompanied by a significant decrease in their overall numbers in the mutant embryos (Fig. 5a, hatched bars). The proportion of apoptotic neural crest cells was determined by double staining, by use of the TUN EL method and p75 NTR -specific antibodies (Fig. 5b; cf. Fig. $4 \mathrm{~g}$ and $\mathrm{h}$ ). No significant increase in the proportion of apoptotic cells was observed in control and mutant embryos in the dorsal compartment (Fig. 5b, dark gray bars) or along the migratory route and at the target site of sympathogenic neural crest cells (Fig. 5b, light gray bars). Thus, the observed changes in distribution of neural crest cells do not correlate with increased cell death in mutant E9 embryos.

Neuregulin-1 expression and the migratory route of sympathogenic neural crest cells

We characterized the time course of neuregulin-1 expression during migration of trunk neural crest cells. When migration of neural crest cells starts, only the type I isoform of neuregulin-1 is expressed at detectable levels; expression of this isoform can be followed by the use of a neuregulin-1-lacZ allele (M eyer et al. 1997). On E9 or 
Figure 2. A ppearance of the sympathetic nervous system in embryos with mutant erbB2, erbB3, or neuregulin-1 genes. The anlage of the sympathetic nervous system was visualized by in situ hybridization with a Phox2a-specific probe on E10.5 embryos. Control embryos heterozygous for the erbB2 (a), the erbB3 (c), and the neuregulin-1 (e) mutations. Embryos homozygous for the erbB2 (b), erbB3 (d), and neuregulin-1 (f) mutations. (Arrowheads) Residual Phox2a-positive cells in the rostral portion of the sympathetic nervous system; (arrows) position of the caudal anlage of the sympathetic nervous system. Magnifications of $a-d$ and $e-f$ are identical, respectively.

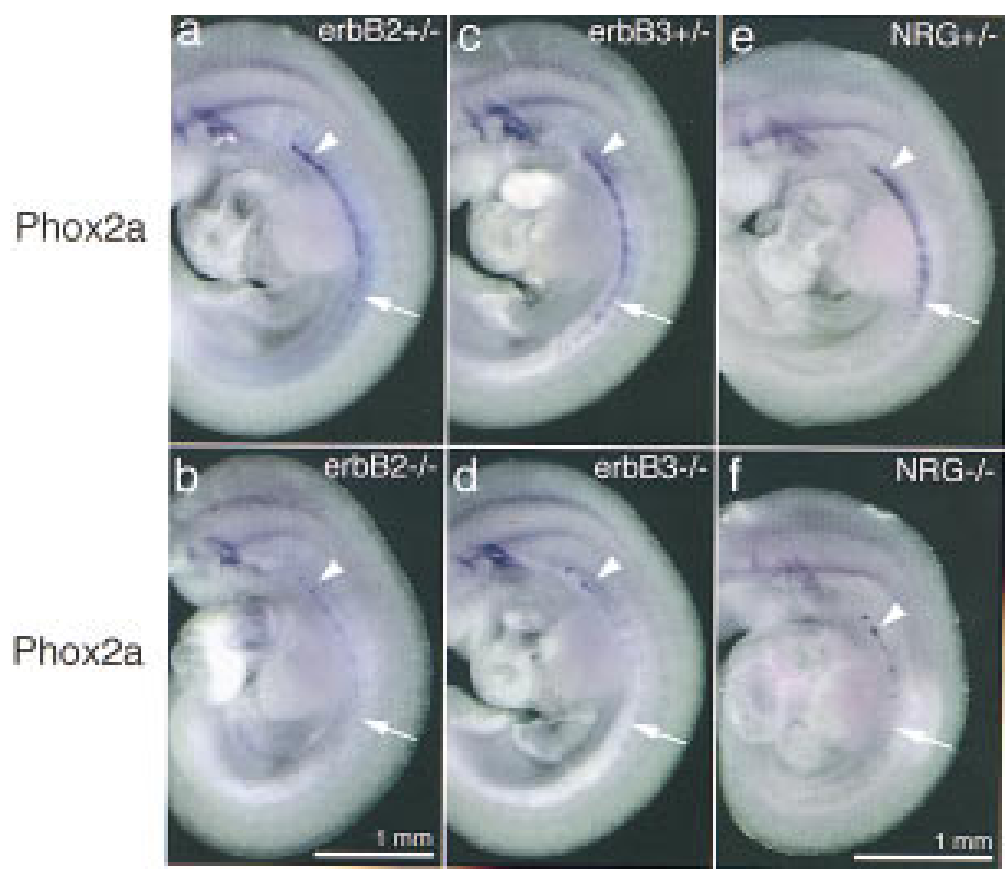

somites express type I neuregulin-1 on E9 (Fig. 6a,b; see arrowhead). On sections, the expression is assigned

dorsal neural tube (Fig. 6). Moreover, newly formed
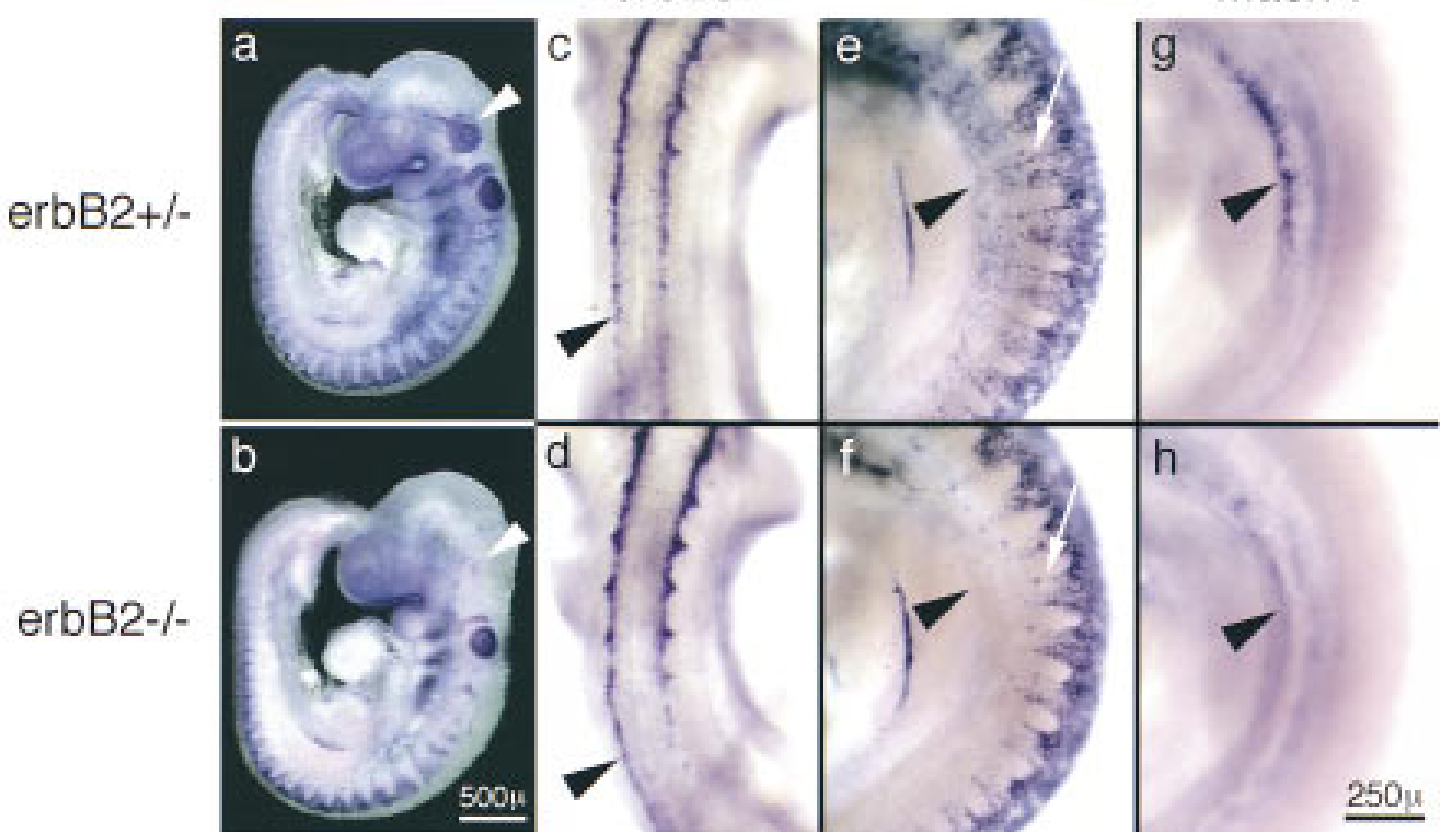

Figure 3. Migrating neural crest cells visualized by in situ hybridization with erbB3-specific probes in embryos heterozygous (a,c,e) or homozygous $(b, d, f)$ for the erbB2 mutation. Lateral view of the entire E9 embryos $(a, b)$. Dorsal view of the embryos showing neural crest cells which emerged form the neural tube (c,d). M agnification of a lateral view on the forelimb level, showing streams of neural crest cells that migrate to the anlage of dorsal root and sympathetic ganglia (e,f). For comparison, the anlage of the sympathetic nervous system is visualized by in situ hybridization with M ash-I in embryos heterozygous ( $\mathrm{g}$ ) or homozygous for the mutant erbB2 (h) gene. Arrowheads in $a$ and $b$ indicate neural crest cells at the anlage of the trigeminal ganglion; arrowheads in c and $d$ point to neural crest cells that have emerged from the neural tube; arrowheads in e-g indicate the anlage of the sympathetic nervous system; and arrows in e and $f$ point toward the streams of neural crest cells that migrate to the anlage of the dorsal root ganglia. Magnifications in $a, b$, and $\mathrm{c}-\mathrm{h}$ are identical, respectively. 


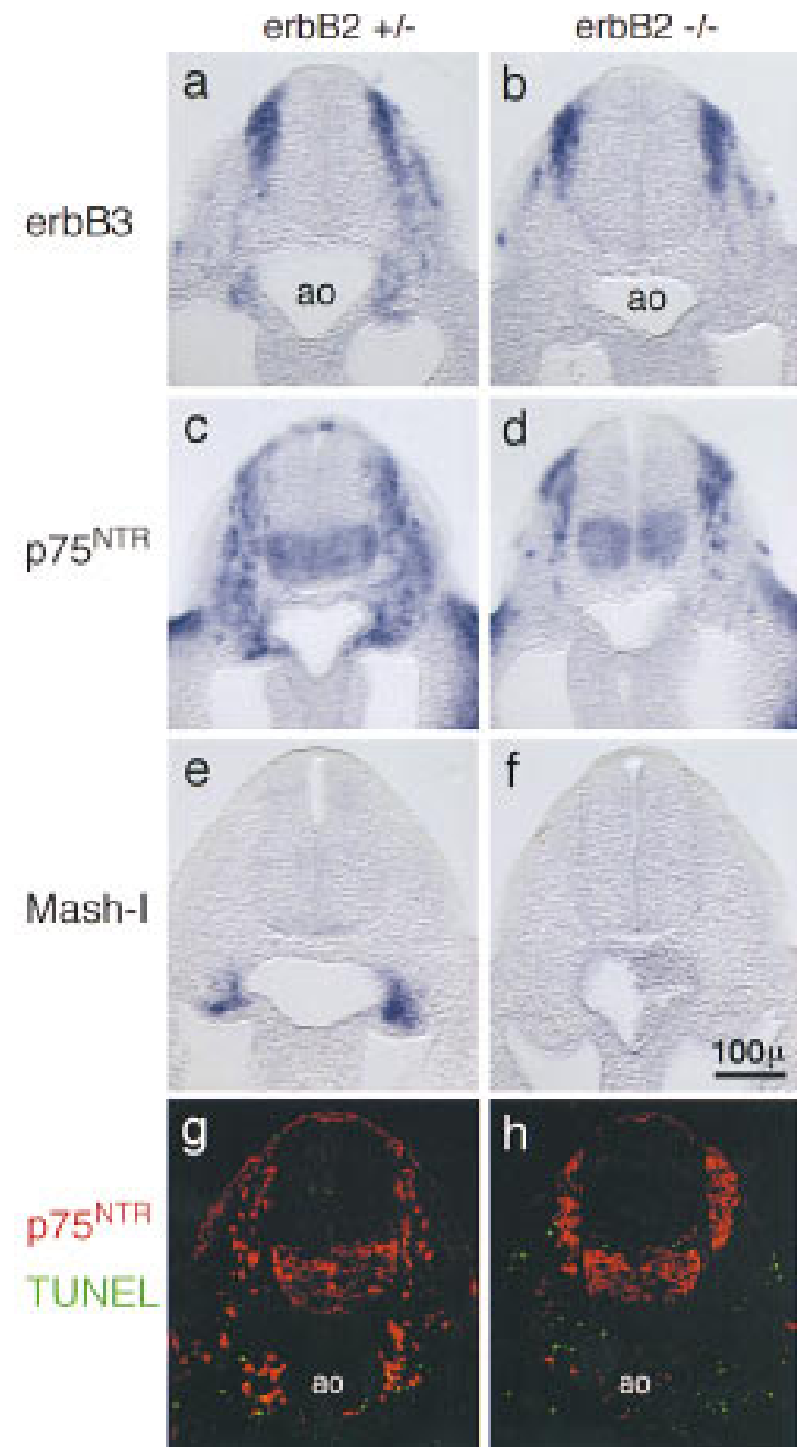

Figure 4. Migration of neural crest cells and the anlage of the sympathetic ganglion chain in control $(a, c, e, g)$, and erbB2 $(b, d, f, h)$ mutant E9 embryos. Shown are $50-\mu \mathrm{m}$ vibratome sections (a-f) or 5- $\mu \mathrm{m}$ frozen sections (g,h). Migrating neural crest cells were visualized by in situ hybridization with probes specific for ErbB3 $(a, b)$ or for the low-affinity N GF receptor p75 NTR $(c, d)$. The anlage of the sympathetic nervous system was visual ized by in situ hybridization with a M ash-1-specific probe (e,f). Distribution and cell death of neural crest cells were analyzed by immunohistochemistry using anti-p $75^{\mathrm{NTR}}$ antibodies (red) combined with a TUN EL analysis of apoptotic cells (green) (g,h). The dorsal aorta (ao) is indicated. Magnifications in $a-h$ are identical.

mainly to the sclerotome (Fig. 6d). Further rostrally, expression is found in the mesenchyme underlying the somites on E9 (Fig. 6a,b, see arrow). This domain corresponds to a broad stripe of mesenchyme flanking the dorsal aorta (Fig. 6e). With maturation (E10), this broad domain becomes restricted to mesenchyme located bilaterally of the dorsal aorta (Fig. 6c,f). Thus, expression of a

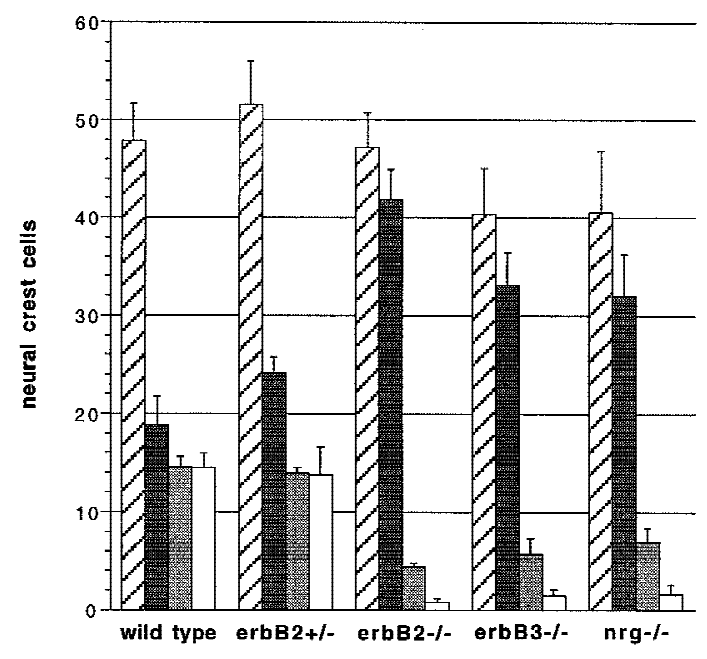

b

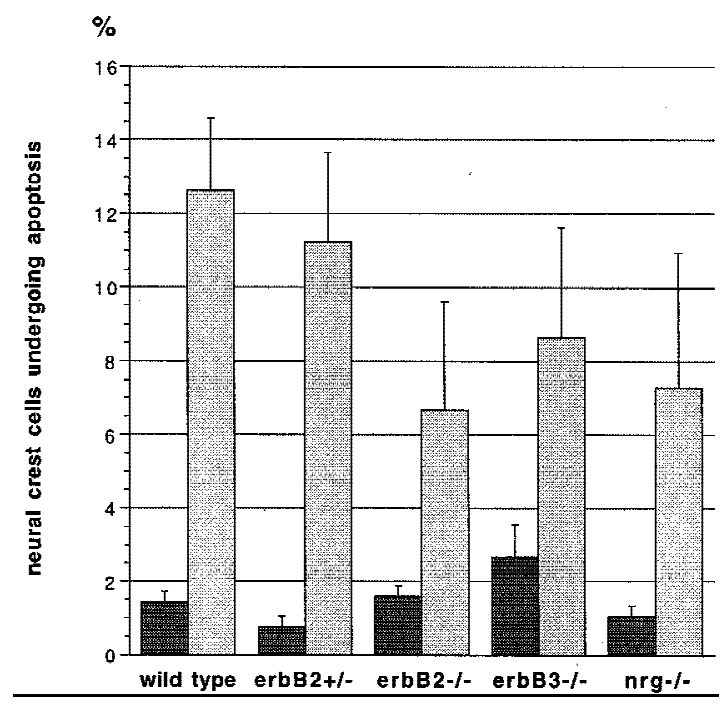

Figure 5. N umbers and incidence of cell death of neural crest cells located in distinct areas in control (wild-type or erbB2 ${ }^{+/}$) and mutant [erbB2 $2^{-1-}$, erbB3 $3^{-1-}$, and neuregulin- $1^{-1-}\left(\mathrm{nrg}^{-1-}\right)$ ] embryos. Consecutive transverse sections of E9 embryos (20-22 somites) that together covered the entire forelimb were analyzed by immunohistochemistry by use of anti-p $75^{\mathrm{NTR}}$ antibodies; this was combined with a TUN EL analysis to identify apoptotic cells. N eural crest cells identified by p $75^{\text {NTR }}$ immunofluorescence were counted and the average number per section was determined (a). Depicted are total numbers of neural crest cells (hatched bars), numbers of neural crest cells grouped in a dorsal position (dark gray), migrating farther ventrally (light gray) and located at the target site in the mesenchyme lateral of the dorsal aorta (white); numbers \pm S.E.M. are displayed. In addition, the numbers of apoptotic neural crest cells identified by $p 75^{\text {NTR }}$ immunofluorescence and TU N EL staining were determined (b). Shown are the percentages \pm S.E.M. of neural crest cells undergoing apoptosis that are located in a dorsal position (dark gray) and neural crest cells that are either migrating or located at the target (light gray bars). $\mathrm{n}=5$ embryos (wild-type, erbB2 ${ }^{+/-}$, erbB2 $^{-1-}$, and erbB $3^{-1}$ ) or $n=3$ embryos (neuregulin- $1^{-1-}$ ). 
Figure 6. Expression of type I neuregulin-1 during migration of neural crest cells and the formation of the sympathetic nervous system. Wholemount $\beta$-galactosidase staining of embryos heterozygous for the neuregulin $n^{\text {lacz }}$ al lele on $\operatorname{E9}(a, b)$ and E10 (c); cross sections of the embryo shown in $\mathrm{a}$ and $\mathrm{b}$ on a caudal (d) and upper forelimb level (e); cross section of the E10 embryo shown in c on the forel imb level (f). Lines in a indicate the level of the section shown in $d$ and e. The arrowhead in b points to somite-associated neuregulin-1 expression; arrows in b and c point to the mesenchyme-associated neuregulin expression bilateral of the dorsal aorta (ao).

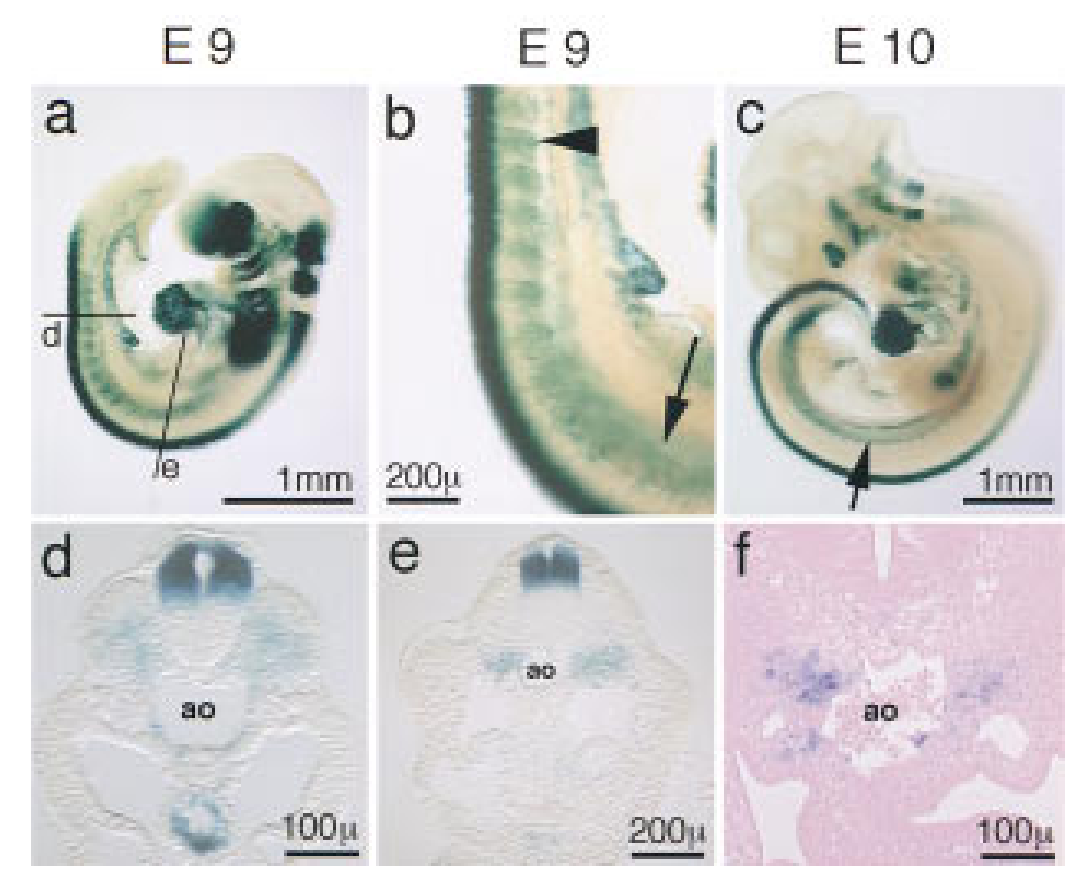

neuregulin-1 is observed at the origin of neural crest cells, as well as al ong the migratory route and the target site of sympathogenic neural crest cells. However, expression seems not to depend on neural crest cell migration: Embryos homozygous for the neuregulin-1 $1^{\text {lacz }}$ allele show an identical expression pattern of type I neuregulin-1, although they display the above described severe reduction in the numbers of neural crest cells that migrate to the dorsal aorta (data not shown). Expression of a distinct neuregulin-1 isoform, type III, begins on E10 in sensory and motoneurons when these neurons differentiate (Meyer et al. 1997). Preliminary evidence indicates that embryos that produce only type III neuregulin1 , that is, that carry the neuregulin-1 ${ }^{\prime g}$ mutation (Kramer et al. 1996), show a similar defect in the development of the primary sympathetic ganglion chain. We conclude, therefore, that it is the type I isoform of neuregulin-1 that is important in the initial development of the sympatho-adrenergic lineage.

Phenotypes in the sympathetic nervous system of erbB3 mutant embryos at later stages of development

erbB2 and neuregulin-1 mutant embryos die at mid-gestation (Lee et al. 1995; M eyer et al. 1995) and, thus, soon after the early defects in formation of the sympathetic nervous system become apparent. erbB3 mutants, however, can survive to birth (Riethmacher et al. 1997) and were used for analysis of the sympathetic nervous system at later developmental stages.

In situ hybridization with a Phox2a or TH-specific probe on E12.5 embryos demonstrated a small change in the size of superior cervical ganglia and a severe defect in the more posterior portion of the sympathetic ganglion chain (Fig. 7a-d), that is, the presence of a rostral-caudal gradient in the severity of the phenotype in the sympa- thetic nervous system. Similarly, a drastic reduction in the numbers of cells that migrate from the posterior portion of the primary ganglion chain to the mesentery or the anlage of the adrenal gl and was apparent (see arrowheads). In contrast, no change in neural crest cells that populate the gastrointestinal tract was observed by in situ hybridization anal ysis with c-Ret (Fig. 7e,f).

Histological analysis of erbB3 mutant embryos on E17.5 demonstrated a hypopl asia of the superior cervical ganglion (Fig. 8a,b) that was also apparent by immunofluorescence analysis with antibodies against neurofilament and TH (Fig. 8c,d). From consecutive sections of embryos ( $n=3$ for mutant or control embryos), we estimate the size of the superior cervical ganglion to be re duced by half. Only residues of the celiac and mesenteric ganglia were present, as assessed by histological criteria and by immunohistochemical analysis (Fig. 8e,f). Throughout the residual sympathetic nervous system, neurofilament positive fibers appeared more coarse and their diameter was increased; immunohistochemistry with B-FA BP-specific antibodies (Kurtz et al . 1994) demonstrated the presence of satellite cells in the superior cervical ganglion (not shown). Chromaffin cells of the adrenal medulla were completely absent when analyzed histologically (Fig. 9a,b) or by immunohistochemistry with anti-TH antibodies on E17.5 (Fig. 9c,d) or at earlier stages (E13, E14). The cortex of the adrenal gland was present, but the columnar organization of the epithelia appeared disorganized on E17.5 (Fig. 9a,b).

Embryonal catecholamine bi osynthesis occurs in sympathetic ganglia and the adrenal medulla, structures that are severely affected by the erbB3 mutation. Catecholamines were shown recently to be essential for fetal development (Thomas et al. 1995; Zhou et al. 1995). Specifically, mutation of the TH or DBH genes, which encode key enzymes in catecholamine biosynthesis, 
ErbB2/ErbB3 and sympathetic nenvous system

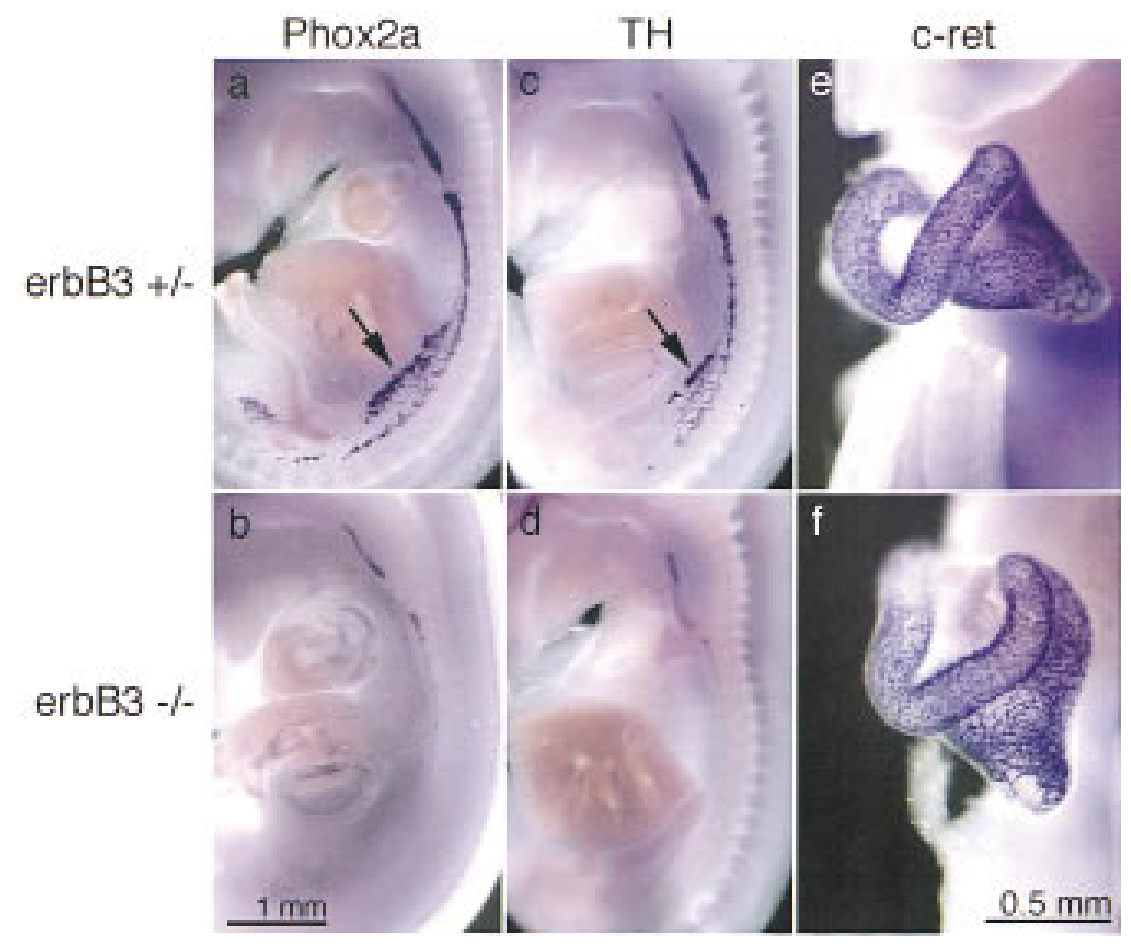

Figure 7. A ppearance of the primary sympathetic ganglion chain and the anlage of the enteric nervous system in $\mathrm{erbB}^{+/-}$ $(a, c, e)$ and erbB3 $3^{-1-}(b, d, f)$ embryos on E12.5. Phox-2a $(a, b)$, or TH $(c, d)$-specific probes were used to visualize the primary sympathetic ganglion chain and a c-Ret (e,f)-specific probe to observe enteric ganglia by in situ hybridization. The embryos were cut at the midline prior to hybridization. Arrows in a and c point to cells that dissociate from the primary sympathetic ganglion chain and migrate to the mesentery and the anlage of the adrenal gland. M agnifications in a-d and e and $f$ are identical, respectively. reduces embryonal survival. Direct measurements of noradrenaline, the only catecholamine observed in significant amounts on E12.5, demonstrate a 15-fold reduction in erbB3 mutant embryos (wild-type, $1.92 \pm 0.11 \mathrm{ng}$ of noradrenaline/mg of protein; erbB3 ${ }^{+1}, 1.53 \pm 0.22 \mathrm{ng}$ of noradrenaline/mg of protein; erbB3 ${ }^{-1}, 0.13 \pm 0.02 \mathrm{ng}$ of noradrenaline/mg of protein). A similar dramatic reduction of noradrenal ine was measured in DBH mutant embryos (Thomas et al. 1995).

\section{Discussion}

By the analysis of erbB2, erbB3, and neuregulin-1 mutant mice, we demonstrate here that the devel opment of the sympathetic nervous system requires an intact neuregulin signaling system. Neural crest cells of the trunk depend on neuregulin-1 and the ErbB2 and ErbB3 receptors to migrate to the mesenchyme lateral of the dorsal aorta where they form the anlage of the sympathetic nervous system. Only the initial steps in development of the sympathetic nervous system can be studied in neuregulin-1 and erbB2 mutant mice (the embryos die at midgestation as a result of a lack of trabeculation of the embryonic heart ventricles). Because a proportion of erbB3 mutants devel op to term, the phenotype could be studied during further devel opment of the sympathetic nervous system. erbB3 ${ }^{-1-}$ mice display a complete absence of the adrenal medulla and only remnants of the cel iac gangli on, whereas the superior cervical ganglion is less affected.

\section{Neuregulin-1 and migration of neural crest cells}

The numbers of neural crest cells that move to and reach the mesenchyme lateral of the dorsal aorta are severely reduced in embryos with mutations in erbB2, erbB3, or neuregulin-1. Principally, three different mechanisms might cause the observed reduction: (1) apoptosis of migrating neural crest cells; (2) impaired proliferation of neural crest cells; or (3) impaired migration of neural crest cells. Increase in proliferation and suppression of apoptosis are typical cellular responses observed on growth factor signal ing in vitro (Schl essinger and Ull rich 1992; Hunter 1997). However, motility of cells can al so be regulated by tyrosine kinase receptors through modulation of adhesiveness, the control of cytoskeletal dynamics or the expression of proteases. Our data do not support a primary role of the neuregulin signaling system in the survival of neural crest cells of the trunk, but rather indicate a defect in migration. At the time the phenotypic changes are first apparent (E9), neural crest cells al ong the migratory route or at the target site do not display an increase in apoptosis in erbB2, erbB3, or neuregulin-1 mutant mice. Neural crest cells are known to proliferate during their migration (Le Douarin and Dupin 1993). Progression through a region unable to provide a growth factor signal or migration away from a source of growth factor could, in principle, result in progressively reduced numbers of neural crest cells, and such a mechanism would be in accordance with the decreasing numbers of neural crest cells ventral of the neural tube. However, a defect in proliferation would not cause the apparent positional arrest of neural crest cells that we observed at dorsal positions in mutant embryos on E9, that is, at the time the phenotype first becomes apparent (Fig. 5). The significant accumulation of neural crest cells at dorsal positions is in accordance with a function of the neuregulin signaling system in migration: $\mathrm{N}$ eural 


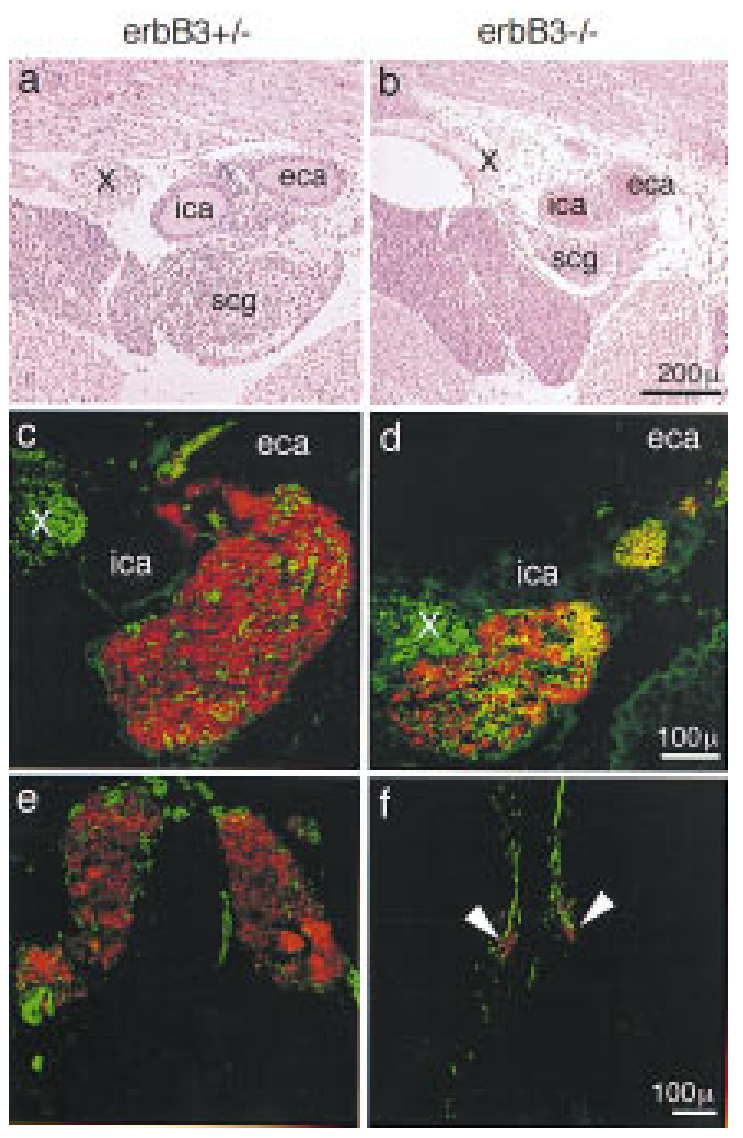

Figure 8. Appearance of the superior cervical ganglion (a-d) and the celiac ganglion $(e, f)$ in control $(a, c, e)$ and erbB3 mutant $(b, d, f)$ embryos on E17.5. Histological sections were stained with hematoxylin/eosin $(a, b)$. Double immunofluorescence analysis on frozen sections with anti-TH (red) and anti-neurofilament 160 (green) antibodies (c-f). Superior cervical ganglia (scg), internal (ica) and external (eca) carotid artery, and the Xth cranial nerve $(X)$ are indicated. Sectional levels were matched by the presence of the bifurcation of the carotid artery $(a-d)$ and the origin of the mesenteric artery. Arrowheads point to the residue of the celiac ganglion of an erbB3 mutant embryo.

crest cells of mutant embryos appear unable to maintain their mobility, cease to migrate prematurely and therefore accumulate dorsally.

The question arises as to what happens to the supernumerous neural crest cells that are located at a dorsal position in the trunk of E9 embryos. It should be noted that numbers of cells in dorsal root ganglia, which are generated at the dorsal positions, are not increased in erbB2 or erbB3 mutants on E10 or E12. Therefore, some mechanism that adjusts the numbers of neural crest cells and their derivatives must exist, and the aberrant distribution of neural crest cells observed on E9 might be adjusted at later stages by a decrease in their growth or survival.

Interestingly, the dynamic expression pattern of the type I isoform of neuregulin-1 (also known as NDF or heregulin) coincides with the origin, the migratory route and the target of neural crest cells that generate the pri- mary sympathetic ganglion chain. The dorsal neural tube expresses type I neuregulin-1 and is located in the vicinity of migrating cel Is. Expression is al so observed in newly formed somites, subsequently in a broad stripe of mesenchyme ventral of the somites, and finally, lateral of the dorsal aorta. We observe severe reductions in the numbers of migrating and differentiating neural crest cells in neuregulin-1, erbB2, or erbB3 mutant mice at sites where the type I isoform of neuregulin-1 is expressed, that is, in the mesenchyme ventral of the somites or lateral of the dorsal aorta. Presently, it is unclear how far type I neuregulin-1 can diffuse in the embryo. Type I neuregulin-1 does not contain a typical amino-terminal signal sequence. Rather, an internal stretch of hydrophobic amino acids is present, which was suggested to function as an internal signal sequence and/or transmembrane domain (Holmes et al. 1992; Wen et al. 1992). The type I isoform can al so bind to heparin (Wen et al. 1992), a property known to immobilize growth factors within the extracellular matrix and to restrict their diffusion. It is therefore possible that this isoform of neuregulin-1 stays closely associated with its site of production. This would imply that type I neuregulin-1 is available only to those migrating neural crest cells that come into immediate contact with those cells that produce the factor. Alternatively, type I neuregulin-1 might be free to diffuse over some distance in the embryo; thus, factor produced by cells in the dorsal neural tube could al so be accessible to neural crest cells that migrate to the anlage of the sympathetic ganglion chain.

In cell culture, neuregulin-1 and the ErbB4 receptor have been implied previously in the control of neuronal migration along radial glial cells in the central nervous system (A nton et al. 1997; Rio et al. 1997). Interestingly,

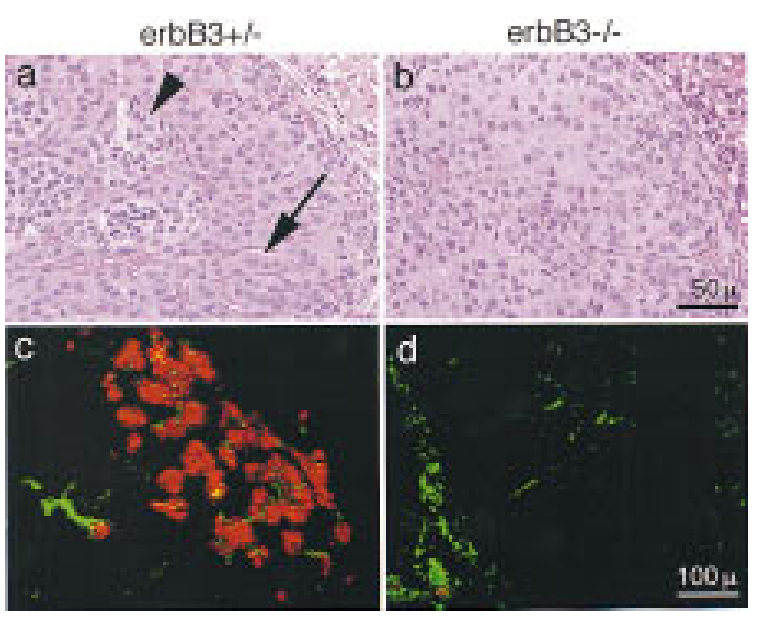

Figure 9. Appearance of the adrenal medulla in control $(a, c)$ and erbB3 mutant (b,d) embryos on E17.5. Histological sections were stained with hematoxylin/eosin $(a, b)$; (arrowhead) indicates islets of chromaffin cells within the adrenal gland. The arrow points to ordered columns of epithelial cells in the adrenal cortex. Double immunofluorescence analysis of frozen sections of the adrenal gland with anti-TH (red) and anti-neurofilament (green) antibodies (c,d). 
expression of a transdominant ErbB4 receptor in the glial compartment inhibits the neuregulin-dependent migration of neuronal precursor cells. Thus, in this system, neuregulin-1 does not affect neuronal cells and their migratory behavior directly. In contrast, neuregulin-1 was reported to directly increase the motility of Schwann cells in cell culture (M ahanthappa et al. 1996).

Independent populations of neural crest cells depend on neuregulin-1 signals

Several undifferentiated neural crest cell populations depend on neuregulin-1 and the ErbB2 and ErbB3 receptors, and can be distinguished by their position in the embryo. We describe here an essential role in the migration of sympathogenic neural crest cells; previously, a role in development of neural crest cells that generate cranial sensory ganglia and Schwann cell precursors was established (Lee et al. 1995; Meyer and Birchmeier 1995; Erickson et al. 1997; Meyer et al. 1997; Riethmacher et al. 1997). This neuregulin dependence does not seem to correlate with a differential expression of the receptors in these specific subpopulations: ErbB3 is also expressed at high levels in neural crest cells not affected by mutation of neuregulin signaling system, whereas ErbB2 is expressed broadly in the developing embryo.

Hindbrain neural crest cells and placodal cells that derive from the ectoderm both contribute to cranial sensory ganglia (N oden 1993); in neuregulin-1, erbB2, and erbB3 mutant mice, cranial sensory ganglia are severely reduced in size because of a decreased contribution of neural crest cells (Lee et al. 1995; M eyer and Birchmeier 1995; Erickson et al . 1997; Riethmacher et al. 1997). The type I isoform of neuregulin-1 (also known as NDF or heregulin) provides the essential signal and is expressed at sites of cranial ganglia formation (Meyer et al. 1997). Previously, the exact mechanism by which neuregulin-1 exerts its essential role was not determined. Because generation of hindbrain neural crest cells is not affected in mutant embryos (Meyer and Birchmeier 1995), it is possible that neuregulin-1 exerts a similar function during formation of sympathetic and cranial sensory ganglia.

M oreover, neuregulin-1 and its receptors, ErbB2 and ErbB3, are also required during development of early Schwann cell precursors that accompany sensory and motoneurons (M eyer and Birchmeier 1995; Riethmacher et al. 1997). These cells are severely reduced in numbers at an early stage of their development, at which they still express genes characteristic for neural crest cells. At later stages, Schwann cell precursors that express Schwann cell specific genes (Krox-20, S-100) cannot be detected along sensory and motoneurons (Riethmacher et al. 1997). We have demonstrated previously that this population of cells depends on a distinct neuregulin-1 isoform, type III (also known as SMDF), which is produced by differentiated sensory and motor neurons (Meyer et al . 1997). Whether type III neuregulin-1 drives growth and/or migration of these cells remains to be elucidated.
In erbB3 mutant mice, the absence of Schwann cell precursors that accompany sensory and motoneurons also severely affects survival of these neurons. These neurons differentiate initially in an appropriate manner before they undergo cell death, and erbB3 is not required in a cell autonomous manner for their survival. Therefore, we attribute the cell death of sensory and motoneurons to a lack of survival factors that are usual ly provided by Schwann cell precursors that accompany these neurons (Riethmacher et al . 1997). The phenotype observed in postmitotic sensory and motoneurons is therefore caused by a mechanism distinct from the one in sympathetic neurons, because sympathogenic precursor cells (neural crest cells) require neuregulin-1 to migrate to their target. Accordingly, the reduction in numbers of sympathetic neurons and their precursors as well as the rostrocaudal gradient in the severity of this phenotype is observed during all stages of development (E9-E17).

Lineage anal yses indicate that neural crest cells of the postotic hindbrain and of the trunk contribute to the anlage of the sympathetic nervous system (Le Douarin 1986; Durbec et al. 1996). In particular, hindbrain neural crest cells can contribute to the superior cervical ganglion in mice (Durbec et al. 1996). Therefore, the moderate effect of the mutations on the superior cervical ganglion might reflect the fact that this ganglion is produced mainly by sympathogenic neural crest cells from the hindbrain that do not require the neuregulin signaling system. In contrast, the caudal portion of the sympathetic nervous system is formed by trunk neural crest cells that depend on neuregulin-1. However, it should be noted that our analysis does not exclude subtle roles of neuregulins after the formation of the primary sympathetic ganglion chain. For instance, trophic support of sympathetic neurons or their precursors might be directly or indirectly regulated by neuregulins (see Verdi et al. 1996). Such possible roles are difficult to assess in mutant embryos because of the large deficits that al ready occur during the formation of the primary ganglion chain.

We show here that the severity of defects in the sympathogenic neural crest cells is identical in neuregulin-1, erbB2, and erbB3 mutant embryos on E10; this is also apparent for the changes in cranial sensory ganglia and early Schwann cell precursors that are observed on E10. Together, these data indicate that ErbB2 provides an essential coreceptor function for ErbB3 during initial development of neural crest cells. However, a direct comparison of neuregulin-1 and erbB2 mutant mice shows that small differences in phenotypes exist between neuregulin-1 and erbB2 mutants: neuregulin-1 $1^{-1}$ embryos die at a slightly earlier stage than in erbB2 ${ }^{-1-}$ embryos (E10.5 vs. E10.75). M oreover, on E10.5, the overall size of the neuregulin-1 mutants appears reduced compared with erbB2 $2^{-1-}$ embryos. Although heart morphologies are similar in the two mutant strains, the small difference in survival and overall appearance indicate that differences in the severity of the heart phenotypes might exist. ErbB4 is the receptor essential for recognition of the neuregulin in the myocardium; the small difference 
might indicate that residual signaling of ErbB4 occurs in the absence of ErbB2, but not in the absence of neuregulin-1.

\section{Catecholamine biosynthesis of erbB3 mutant embryos}

The majority of erbB3 mutant embryos die within a broad window of time between E11.5 and E13.5. In embryos at this stage, the most abundant catecholamine is noradrenaline (Thomas et al. 1995). Direct measurements demonstrate a significant reduction in noradrenal ine levels in erbB3 mutant animals on E12.5. Catecholamines function as neurotransmitters and hormones and regulate visceral functions, motor coordination, and arousal in adults. By ablation of the genes encoding key enzymes of catecholamine biosynthesis (TH or DBH), it was recently demonstrated that catecholamines are essential during embryonic development (Thomas et al. 1995; Zhou et al. 1995). The time course and proportion of embryonal death are virtually identical for $\mathrm{TH}$ and erbB3 mutant embryos, and similar for DBH mutants. Therefore, it is possible that a lack of catecholamines in erbB3 mutants contributes to the embryonal lethality observed.

Tyrosine kinase receptors and the control of migration during devel opment

Genetic analysis in the mouse has demonstrated that tyrosine kinase receptors take over pivotal roles in the control of cell migration during development. These functions can be exerted during multiple stages in the migratory process. Migrating cells are frequently generated from epithelia by an epithelial-mesenchymal conversion. The c-M et receptor induces an epithelial-mesenchymal conversion of dermomyotomal cells in vivo, and thus controls emigration of a motile cell population with myogenic potential (Bladt et al. 1995; Brand-Saberi et al . 1996; Heymann et al. 1996). Here, we provide evidence for a role of the ErbB2/ErbB3 receptors in the maintenance of the migratory ability of sympathogenic neural crest cells. It will be of interest to analyze changes in the migratory patterns of neural crest cells in animals that express neuregulin-1 at ectopic sites. Signals mediated by tyrosine kinase receptors seem to eli cit a range of distinct cellular responses in neural crest cells and their derivatives. Along with ErbB2/ErbB3 function in migration, the c-Ret receptor provides a survival signal, whereas the c-Kit receptor was reported to el icit complex cellular responses that affect survival, growth, and migration of melanocyte precursors (Wehrle-Haller and Weston 1997).

\section{Materials and methods}

Mutant mouse strains

Genomic erbB2 DN A was isolated from a $\lambda$ genomic library of 129 mouse DN A and used to construct the erbB2 targeting vector. A lacZ-neo cassette was fused in-frame to exon h encoding the cytoplasmic juxtamembrane domain of ErbB2; the point of fusion corresponds to nucleotide position 2316 in the human
CDNA (nomenclature of ErbB2 exons and numbering of the CDNA are according to Semba et al. 1985). The predicted chimeric ErbB2 protein produced from the allele contains the entire extracellular, transmembrane, and 39 amino acids of the cytoplasmic domain that are fused to the bacterial $\beta$-galactosidase (Fig. 1a). The targeting vector was introduced into E14.1 ES cells (Kühn et al. 1991) by electroporation. Homologous recombination events were enriched by sel ection with G418 and identified by Southern hybridization. The structure of the targeted locus and the presence of a single insertion event were verified by Southern hybridization on ES cell DNA. Two independently mutated ES cell clones were used to generate chimeric animals by blastocyst injection (Bradley 1987). The phenotypes were anal yzed on a C 57BL/6/ 129 hybrid background. The generation of targeted mutations in the mouse neuregulin-1 (Meyer and Birchmeier 1995) and the erbB3 (Riethmacher et al. 1997) genes has been described elsewhere. Homozygous mutant animals were obtained by matings of heterozygous animals. Genotype of animals and embryos was determined by PCR.

\section{Protein analysis}

Protein extracts of embryonic hearts were immunoprecipitated with an antibody against a carboxy-terminal ErbB2 peptide (Santa Cruz). Immunoprecipitates were electrophoresed on a SDS-polyacrylamide gel and transferred to nitrocellulose. ErbB2 protein was detected with the anti-carboxy-terminal ErbB2 antibodies using the ECL Western blotting detection system (Amersham).

In situ hybridization, X-gal staining, histology, and immunohistochemistry

Digoxigenin (DIG)-labeled riboprobes were produced with a DIG-RN A labeling kit (Boehringer, Mannheim). In situ hybridizations on mouse embryos from E9 to E13.5 were performed as described (Wilkinson 1992). The probe for ErbB3 was described (Meyer et al. 1997). For vibratome sectioning, stained embryos were embedded in $4 \%$ agarose.

$X$-gal staining was performed essentially as described (Sham et al. 1993). After staining, the embryos were washed in PBS and refixed in $4 \%$ paraformal dehyde.

For histological analysis, mouse embryos were fixed in $4 \%$ PFA for several days at $4^{\circ} \mathrm{C}$, dehydrated, and embedded in Technovit 7100 resin (Kulzer); 6 - to $8-\mu \mathrm{m}$ sections were stained with hematoxilin/eosin.

For immunohistological analysis, E17.5 embryos were embedded in OCT (Miles). Cryosections $(6 \mu \mathrm{m})$ were fixed for 15 min in $4 \%$ PFA, blocked with $20 \%$ goat serum (GS) in PBT (PBS/0.1\% Tween 20), and incubated with monoclonal antineurofilament 160 antibody (clone N N 18, Sigma, 1:1000) and a rabbit polyclonal anti-TH antibody (Pel-Freez, 1:200) in PBT/ $5 \% \mathrm{GS}$ at $4^{\circ} \mathrm{C}$ overnight. As secondary antibodies, Cy2-conjugated anti-mouse IgG (1:300) and Cy3-conjugated anti-rabbit IgG (1:300) antibodies (Dianova) were used. The sections were examined with a Leica confocal microscope.

Determination of numbers and apoptosis rates of neural crest cells

Embryos were staged according to their somite numbers (20-22 somites) and overall appearance. Consecutive frozen sections that together covered the entire forel imb regi on were produced; every third section was double stained by the TUNEL method with the ApopTag kit (Oncor) and a polyclonal anti-p75 NTR (Promega) combined with a Cy3 (Dianova) conjugated secondary antibody. The signals were visualized simultaneously using a Leica confocal microscope. The surface labeling of the neural 
crest cells positive for $\mathrm{p} 75^{\mathrm{NTR}}$ al lowed the outline of the cells to be identified. Cells were classified as apoptotic if TUN EL-positive staining (green) was identified within the area stained or outlined by the p $75^{\mathrm{NTR}}$ immunofluorescence (red). N eural crest cells were classified according to their position in the embryo as residing either in the dorsal compartment, in the migrating compartment, or at the target bilateral of the aorta. Cells in the dorsal compartment were positioned along the dorsal twothirds of the neural tube in the mesenchyme; in mutant embryos, these cells formed frequently dense clusters, that is, the cells appeared to be directly contacting each other. Cells in the migrating compartment were located between the dorsal compartment and the aorta; they were dispersed in the mesenchyme as single cells or small cell groups. Cells in the target compartment were located bilaterally of the dorsal aorta, that is, in the immediate vicinity of the aorta. For each embryo, 10-20 sections were independently counted by two scientists.

\section{Catecholamine measurements}

Catecholamine measurements were performed essentially as described (Thomas et al. 1995). Embryos were homogenized in $0.1 \mathrm{~m}$ perchloric acid containing 3,4-dihydroxybenzylamine as an internal standard; catecholamines were purified over alumina columns and levels were measured by the use of a catecholamine detection kit (Chromsystems) and HPLC chromatography. Protein concentrations in the homogenates were determined by Bio-Rad protein microassay.

\section{Acknowledgments}

This project was initiated at the M ax-Del brück-Laboratorium in der Max-Planck-Gesellschaft in Cologne. We thank D. Meyer for advice in the initial phase of the project, A. Rehaus and S. Buchert for technical assistance, A. Floss and Prof. R. Dietz for hel $p$ with the measurements of catecholamine levels in the embryos, T. Yamaai and H. Rohrer for hel pful discussions, as well as W. Birchmeier, A. Garratt, and F. Rathjen for critical reading of the manuscript. We thank the following scientists for probes used for in situ hybridization and for other plasmid DNA: D.J. Anderson (Mash-I), C. Goridis (Phox2a), L. Tessarollo and L. Reichardt (p75 NTR), H. Baker (TH), V. Pachnis (c-Ret), and F. Sablitzky (a lacZ-neo cassette). This work was supported by grants of the German Israeli Foundation, the Deutsche Forschungsgemeinschaft, and the Bundesministerium für Bildung und Forschung to C.B.

The publication costs of this article were defrayed in part by payment of page charges. This article must therefore be hereby marked "advertisement" in accordance with 18 USC section 1734 solely to indicate this fact.

\section{References}

Anderson, D.J. 1997. Cellular and molecular biology of neural crest cell lineage determination. Trends Genet. 13: 276-280.

Anton, E.S., M.A. Marchionni, K.F. Lee, and P. Rakic. 1997. Role of GGF/neuregulin signaling in interactions between migrating neurons and radial glia in the devel oping cerebral cortex. Development 124: 3501-3510.

Beerli, R.R., D. Grausporta, K. Woodscook, X.M. Chen, Y. Yarden, and N.E. Hynes. 1995. Neu differentiation factor activation of erbb 3 and erbb 4 is cell specific and displays a differential requirement for erbb 2. Mol. Cell. Biol. 15: 64966505.

Bladt, F., D. Riethmacher, S. Isenmann, A. Aguzzi, and C. Birchmeier. 1995. Essential role for the c-met receptor in the migration of myogenic precursor cells into the limb bud. Na- ture 376: 768-771.

Bradley, A. 1987. Teratocarcinomas and embryonic stem cells: A practical approach. Oxford University Press/IRL Press, Oxford, UK.

Brand-Saberi, B., T.S. Muller, J. Wilting, B. Christ, and C. Birchmeier. 1996. Scatter factor/hepatocyte growth factor (SF/ HGF) induces emigration of myogenic cells at interlimb level in vivo. Dev. Biol. 179: 303-308.

Burden, S. and Y. Y arden. 1997. N euregulins and their receptors: A versatile signaling module in organogenesis and oncogenesis. Neuron 18: 847-855.

Carraway, K. III and L.C. Cantley. 1994. A neu acquaintance for erbB3 and erbB4: A role for receptor heterodimerization in growth signaling. Cell 78: 5-8.

Cochard, P., M. Goldstein, and I.B. Black. 1978. Ontogenetic appearance and disappearance of tyrosine hydroxylase and catecholamines in the rat embryo. Proc. Natl. Acad. Sci. 75: 2986-2990.

Durbec, P.L., B.L. Larsson, A. Schuchardt, F. Costantini, and V. Pachnis. 1996. Common origin and developmental dependence on c-ret of subsets of enteric and sympathetic neuroblasts. Development 122: 349-358.

Erickson, S.L., K.S. O'Shea, N. Ghaboosin, L. Loverro, G. Frantz, M. Bauer, L.H. Lu, and M.W. M oore. 1997. ErbB3 is required for normal cerebellar and cardiac development: A comparison with erbB2 and heregulin deficient mice. Development 124: 4999-5011.

Ernsberger, U., H. Patzke, S.J. Tissier, T. Reh, C. Goridis, and H. Rohrer. 1995. The expression of tyrosine hydroxylase and the transcription factors CPhox-2 and Cash-1: Evidence for distinct inductive steps in the differentiation of chick sympathetic precursor cells. Mech. Dev. 52: 125-136.

Falls, D.L., K.M. Rosen, G. Corfas, W.S. Lane, and G.D. Fischbach. 1993. ARIA, a protein that stimulates acetylcholine receptor synthesis, is a member of the neu ligand family. Cell 72: 801-815.

Gassmann, M., F. Casagranda, D. Orioli, H. Simon, C. Lai, R. Klein, and G. Lemke. 1995. A berrant neural and cardiac development in mice lacking the erbb4 neuregulin receptor. Nature 378: 390-394.

Groves, A.K., K.M. George, S.J. Tissier, J.D. Engel, J.F. Brunet, and D.J. Anderson. 1995. Differential regulation of transcription factor gene expression and phenotypic markers in developing sympathetic neurons. Development 121: 887-901.

Guillemot, F. and A.L. Joyner. 1993. Dynamic expression of the murine Achaete-Scute homologue M ash-1 in the devel oping nervous system. Mech. Dev. 42: 171-185.

Guillemot, F., L.C. Lo, J.E. Johnson, A. Auerbach, D.J. Anderson, and A.L. Joyner. 1993. Mammalian achaete-scute homolog 1 is required for the early development of olfactory and autonomic neurons. Cell 75: 463-476.

Heymann, S., M. Koudrova, H. Arnold, M. Koster, and T. Braun. 1996. Regulation and function of SF/HGF during migration of limb muscle precursor cells in chicken. Dev. Biol. 180: 566-578.

Ho, W.H., M.P. Armanini, A. Nuijens, H.S. Phillips, and P.L. Osheroff. 1995. Sensory and motor neuron-derived factor. A novel heregulin variant highly expressed in sensory and motor neurons. J. Biol. Chem. 270: 14523-14532.

Holmes, W.E., M.X. Sliwkowski, R.W. Akita, W.J. Henzel, J. Lee, J.W. Park, D. Y ansura, N. A badi, H. Raab, G.D. Lewis et al. 1992. Identification of heregulin, a specific activator of p185erbB2. Science 256: 1205-1210.

Horan, T., J. Wen, T. Arakawa, N. Liu, D. Brankow, S. Hu, B. Ratzkin, and J.S. Philo. 1995. Binding of N eu differentiation factor with the extracellular domain of Her2 and Her3. J. 
Biol. Chem. 270: 24604-24608.

Hunter, T. 1997. Oncoprotein networks. Cell 88: 333-346.

Kramer, R., N. Bucay, D.J. Kane, L.E. Martin, J.E. Tarpley, and L.E. Theill. 1996. Neuregulins with an Ig-like domain are essential for mouse myocardial and neuronal development. Proc. Natl. Acad. Sci. 93: 4833-4838.

Kühn, R., K. Rajewsky, and W. Müller. 1991. Generation and analysis of interleukin-4 deficient mice. Science 254: 707710.

Kurtz, A., A. Zimmer, F. Schnutgen, G. Bruning, F. Spener, and T. Muller. 1994. The expression pattern of a novel gene encoding brain-fatty acid binding protein correlates with neuronal and glial cell development. Development 120: 26372649.

LeDouarin, N.M. 1982. The neural crest. Cambridge University Press, Cambridge, UK.

- - . 1986. Cell line segregation during peripheral nervous system ontogeny. Science 231: 1515-1522.

Le Douarin, N.M. and E. Dupin. 1993. Cell lineage analysis in neural crest ontogeny. J. Neurobiol. 24: 146-161.

Le Douarin, N.M., E. Dupin, and C. Ziller. 1994. Genetic and epigenetic control in neural crest development. Curr. O pin. Genet. Dev. 4: 685-695.

Lee, K.F., H. Simon, H. Chen, B. Bates, M.C. Hung, and C. Hauser. 1995. Requirement for neuregulin receptor erbB2 in neural and cardiac development. N ature 378: 394-398.

Lemke, G. 1996. Neuregulins in development. Mol. Cell. Neurosci. 7: 247-262.

Liem, K.F., G. Tremml, and T.M. Jessell. 1997. A role for the roof plate and its resident TGF beta-related proteins in neuronal patterning in the dorsal spinal cord. Cell 91: 127-138.

Mahanthappa, N.K., E.S. Anton, and W.D. M atthew. 1996. Glial growth factor 2, a soluble neuregulin, directly increases Schwann cell motility and indirectly promotes neurite outgrowth. J. Neurosci. 16: 4673-4683.

Marchionni, M.A., A.D. Goodearl, M.S. Chen, M.O. Bermingham, C. Kirk, M. Hendricks, F. Danehy, D. Misumi, J. Sudhalter, K. Kobayashi et al. 1993. Glial growth factors are alternatively spliced erbB2 ligands expressed in the nervous system. Nature 362: 312-318.

Meyer, D. and C. Birchmeier. 1995. Multiple essential functions of neuregulin in development. Nature 378: 386-390.

Meyer, D., T. Yamaai, A. Garratt, E. Riethmacher-Sonneberg, D. Kane, L. Theill, and C. Birchmeier. 1997. Isoform specific expression and function of neuregulin. Development 124: 3575-3586.

Morin, X., H. Cremer, M.R. Hirsch, R.P. Kapur, C. Goridis, and J.F. Brunet. 1997. Defects in sensory and autonomic ganglia and absence of locus coeruleus in mice deficient for the homeobox gene phox2a. Neuron 18: 1-20.

N oden, D.M. 1993. Spatial integration among cells forming the cranial peripheral nervous system. J. Neurobiol. 24: 248-261.

Plowman, G.D., J.M. Green, J.M. Culouscou, G.W. Carlton, V.M. Rothwell, and S. Buckley. 1993. Heregulin induces tyrosine phosphorylation of HER4/p180erbB4. Nature 366: 473-475.

Reissmann, E., U. Ernsberger, W.P. Francis, D. Rueger, P.M. Brickell, and H. Rohrer. 1996. Involvement of bone morphogenetic protein-4 and bone morphogenetic protein-7 in the differentiation of the adrenergic phenotype in developing sympathetic neurons. Development 122: 2079-2088.

Riese, D.J., T.M. van Raaij, G.D. Plowman, G.C. Andrews, and D.F. Stern. 1995. The cellular response to neuregulins is governed by complex interactions of the erbB receptor family. Mol. Cell Biol. 15: 5770-5776.
Riethmacher, D., E. Sonnenberg-Riethmacher, V. Brinkmann, T. Yamaai, G. Lewin, and C. Birchmeier. 1997. Severe peripheral neuropathies in mice with targeted mutations in the erbB3 receptor. Nature 389: 725-730.

Rio, C., H.I. Rieff, P. Qi, and G. Corfas. 1997. Neuregulin and erbB receptors play a critical role in neuronal migration. Neuron 19: 39-50.

Schlessinger, J. and A. Ullrich. 1992. Growth factor signal ing by receptor tyrosine kinases. Neuron 9: 383-391.

Schuchardt, A., V. D'A gati, B.L. Larsson, F. Costantini, and V. Pachnis. 1994. Defects in the kidney and enteric nervous system of mice lacking the tyrosine kinase receptor Ret. Nature 367: 380-383.

Semba, K., N. Kamata, K. Toyoshima, and T. Y amamoto. 1985. A v-erbB-related protooncogene, c-erbB-2, is distinct from the c-erbB-1/epidermal growth factor-receptor gene and is amplified in a human salivary gland adenocarcinoma. Proc. Natl. Acad. Sci. 82: 6497-6501.

Shah, N.M., A.K. Groves, and D.J. Anderson. 1996. Alternative neural crest cell fates are instructively promoted by TGFbeta superfamily members. Cell 85: 331-343.

Sham, M.H., C. Vesque, S. Nonchev, H. Marshall, M. Frain, R.D. Gupta, J. Whiting, D. Wilkinson, P. Charnay, and R. Krumlauf. 1993. The zinc finger gene Krox20 regulates HoxB2 (Hox2.8) during hindbrain segmentation. Cell 72: 183-196.

Sliwkowski, M.X., G. Schaefer, R.W. Akita, J.A. Lofgren, V.D. Fitzpatrick, A. N uijens, B.M. Fendly, R.A. Cerione, R.L. Vandlen, and K. Carraway III. 1994. Coexpression of erbB2 and erbB3 proteins reconstitutes a high affinity receptor for heregulin. J. Biol. Chem. 269: 14661-14665.

Thomas, S.A., A.M. M atsumoto, and R.D. Palmiter. 1995. N oradrenaline is essential for mouse fetal development. Nature 374: 643-646.

Tiveron, M.C., M.R. Hirsch, and J.F. Brunet. 1996. The expression pattern of the transcription factor phox 2 del ineates synaptic pathways of the autonomic nervous system. J. Neurosci. 16: 7649-7660.

Tzahar, E., G. Levkowitz, D. Karunagaran, L. Yi, E. Peles, S. Lavi, D. Chang, N. Liu, A. Yayon, D. Wen et al. 1994. ErbB-3 and ErbB-4 function as the respective low and high affinity receptors of all $\mathrm{Neu}$ differentiation factor/heregulin isoforms. J. Biol. Chem. 269: 25226-25233.

Verdi, J.M., A.K. Groves, I. Farinas, K. Jones, M .A. Marchionni, L.F. Reichardt, and D.J. Anderson. 1996. A reciprocal cellcell interaction mediated by NT-3 and neuregulins controls the early survival and development of sympathetic neuroblasts. Neuron 16: 515-527.

Wallasch, C., F.U. Weiss, G. N iederfellner, B. Jallal, W. Issing, and A. Ullrich. 1995. Heregulin-dependent regulation of HER2/neu oncogenic signaling by heterodimerization with HER3. EMBO J. 14: 4267-4275.

Wehrle-Haller, B. and J.A. Weston. 1997. Receptor tyrosine kinase dependent neural crest migration in response to differentially localized growth factors. BioEssays 19: 337-345.

Wen, D., E. Peles, R. Cupples, S.V. Suggs, S.S. Bacus, Y. Luo, G. Trail, S. Hu, S.M. Silbiger, R.B. Levy et al. 1992. N eu differentiation factor: A transmembrane glycoprotein containing an EGF domain and an immunogl obulin homology unit. Cell 69: 559-572.

Wilkinson, D.G. 1992. In situ hybridization: A practical approach. Oxford University Press, IRL Press, Oxford, UK.

Zhou, Q.Y., C.J. Quaife, and R.D. Palmiter. 1995. Targeted disruption of the tyrosine hydroxylase gene reveals that catecholamines are required for mouse fetal devel opment. Nature 374: 640-643. 


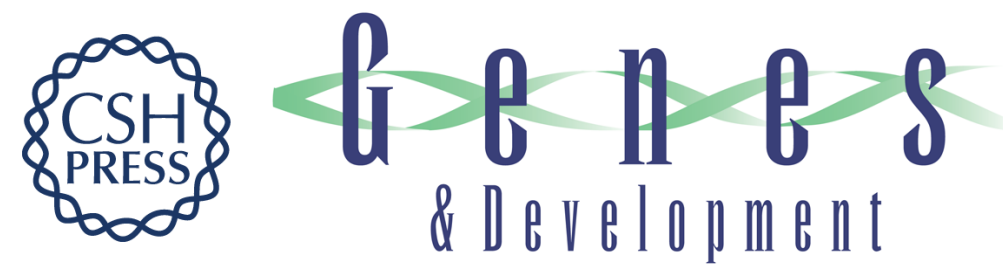

\section{The ErbB2 and ErbB3 receptors and their ligand, neuregulin-1, are essential for development of the sympathetic nervous system}

Stefan Britsch, Li Li, Susanne Kirchhoff, et al.

Genes Dev. 1998, 12:

Access the most recent version at doi:10.1101/gad.12.12.1825

References This article cites 55 articles, 21 of which can be accessed free at: http://genesdev.cshlp.org/content/12/12/1825.full.html\#ref-list-1

License

Email Alerting

Receive free email alerts when new articles cite this article - sign up in the box at the top Service right corner of the article or click here.

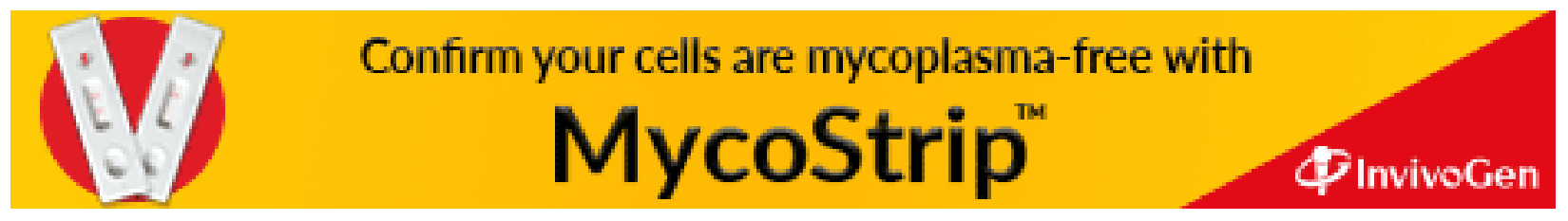

